\title{
Overconfidence and Excessive Trading Behavior: An Experimental Study
}

\author{
Irwan Trinugroho (Corresponding author) \\ Faculty of Economics, Sebelas Maret University \\ J1. Ir. Sutami 36A, Surakarta 57126, Indonesia \\ E-mail: irwan@fe.uns.ac.id; irwan_feuns@yahoo.co.id
}

Roy Sembel

Professor in Finance and lecturer in Department of Management, Faculty of Economics

Christian University of Indonesia, University of Indonesia, Pelita Harapan University, Indonesia

E-mail: roy.sembel@gmail.com

Received: March 16, 2011 Accepted: March 31, $2011 \quad$ doi:10.5539/ijbm.v6n7p147

\begin{abstract}
The main objective of the research is to examine the excessive trading hypothesis, investors who have higher overconfidence shown by high miscalibration levels will tend to practice aggresive and excessive trading strategy. It is an experimental research which combines both between and within subject design. The participants are undergraduate students who have already taken financial management course but have not yet invest in real capital market. The result of the research shows that high overconfidence investors have higher trading activity than low overconfidence investor. The other result shows that among high overconfidence investors, there is no trading activity differences between pre and post bad news, whereas among low overconfidence investors, the existence of bad news cause trading activity to decrease in the post bad news period. Then, the investment returns of high overconfidence investors is significantly lower than that of the low overconfidence investors.
\end{abstract}

Keywords: Overconfidence, Excessive trading, Trading activity, Bad news, Return

\section{Introduction}

In the modern financial theory, investors are assumed to be rational in their efforts to identify and process the relevant information for optimal decisions. But in recent years, emerged a variety of empirical evidence showing the existence of investor behavior that deviates from these predictions (Charness and Gneezy, 2003). The results become anomalous phenomena under the paradigm of efficient markets hypothesis (EMH) that was so dominant earlier that financial asset prices reflect all of relevant information. This is due to the existence of cognitive biases that distort the perception and cause the market price of securities to deviate from its fundamental value. Starting from the empirical facts and the anomalies (with respect to the EMH) that occurred in the capital market, behavioral finance approach was developed. Behavioral finance is generally defined as the application of psychology in finance. Behavioral finance is divided into two topics, behavioral finance macro that detect anomalies described in the EMH, and behavioral finance micro that covers psychological biases of individual investors as opposed to rational behavior suggested by classical economic theory, portfolio theory and EMH (Pompian, 2006). Psychological biases of investors are developed in the study of behavioral finance micro. One of cognitive bias in the behavior of finance is overconfidence, the tendency of decision makers to unwittingly give excessive weight to the assessment of knowledge and accuracy of information possessed and ignore the public information available (Lichtenstein and Fischhoff, 1977). Overconfidence is an irrational behavior because it is not based on the principle of normative rationality, which among others refers to the maximization of expected utility.

Various studies have been conducted to test the effect of overconfidence bias in the financial markets. Bloomsfield et al. (1999) find that overconfidence behavior unconsciously increase prediction error thus creating adverse trading, buy stock too expensive or sell too cheap. Kufepaksi (2007) using an experimental studies concludes that overconfidence behavior is a self-deception behavior that caused an error in predicting stock prices. Other effect of overconfidence behavior is excessive trading or the tendency of investors to trade in the stock market too much (Odean, 1998; Benos, 1998; Odean, 1999; Barber and Odean, 2000; Barber and Odean, 2001; Pompian, 2006; Graham et al., 2005). This is caused by the belief of high overconfidence investors that they have ability and specialized knowledge in the field of stock market investments. This belief causes a tendency to do frequent transactions. Based on empirical research, it was found that the level of investor 
overconfidence affects trading frequency. Higher overconfidence investors tend to trade more frequently (Graham et al., 2006; Grinblatt and Keloharju, 2009).

While other studies have found that high overconfidence behavior affected not only the frequency but also the volume of trading in the stock market. Glaser and Weber (2003) show that high overconfidence investors defined as above than average in investment skill have a tendency to trade in large volumes. Statman et al. (2003) argue that the level of overconfidence has a positive effect on trading volume. Investors with high overconfidence tend to trade in large volume, then modeled as overconfidence hypothesis. Several studies conclude that overconfidence causes excessive trading, and eventually lead to decline in investor returns. Biais et al. (2002) find that the tendency of overconfidence behavior causes investors to invest in stocks that do not provide benefits (unprofitable investment). Kirchler and Maciejovsky (2002) argue that the overconfidence investors who trade too much will experience reduced outcome (earnings) and often invest in stocks that have negative earnings. In the Initial Public Offering (IPO) research, Sembel (1996) find that trading value has a positive correlation with IPO initial return, and the IPO initial return has a negative correlation with the long-term performance.

The other effect of overconfidence is causing investors to underestimate on the risk or tend to ignore the risk (Pompian, 2006). One of investment risk in stock is the risk associated with stock price declines (capital loss). Information related to the global market, macroeconomic, and issuers' fundamentals can be used to explain the increase or decrease in stock prices. The existence of bad news can cause the stock price decline because investors' response to the negative news will result in more sales than purchases. But the investors who have high overconfidence tends to ignore the risk from the information because they have their own beliefs about choice, so that such information should not affect trading activity.

Based on the background, this study tries to examine the effects of overconfidence behavior on trading activity of investors proxied by trading frequency and volume, to test the influence of bad news on trading activities at different levels of overconfidence, and to test the effect of overconfidence on the investors' investment returns. Our study uses experiment design that combine both between and within subject design, employing software of trading simulation.

\section{Literature Review and Hypotheses}

Lichtenstein and Fischhoff (1977) define overconfidence as the tendency of decision makers to unwittingly give excessive weight to the assessment of knowledge and accuracy of information possessed and ignore the public information available. Cheng (2007) suggests that overconfidence behavior is the most common characteristics found in humans that reflect one's tendency to overestimate the ability, the chances for success and the probability that someone will gain positive outcomes and the accuracy of the knowledge possessed.

According to Klayman et al. (1999) and Kufepaksi (2007), a person's overconfidence level can be identified through calibration test of confidence level. Calibration test is a procedure to test and identify the combination of the level of knowledge and level of confidence that shape one's level of overconfidence based on a specific questionnaire designed specifically for these purposes. Overconfidence level is measured by overconfidence score that is the average probability confidence level minus average percentage of the value of correct answer. If the average probability of confidence is lower than average proportion of truth in the assessment, this situation will produce a negative value that reflect the underconfidence behavior. Conversely, if the average confidence probability is higher than average proportion of truth in the assessment, this situation will produce a positive value of overconfidence. Value of overconfidence has three levels: low, medium and high.

In the financial literature, overconfidence is defined as the overestimating valuation in assessing a financial asset (Odean, 1998; Gervais and Odean, 2001; Glaser and Weber, 2003). There are three aspects of overconfidence in finance, namely: (1) Miscalibration, the subjective probability higher than the actual probability, (2) Better-than-average_effect, the tendency to think that someone has an above average ability. (3) Illusion-of-control: a belief that people have more ability to predict or more satisfactory results when they have high involvement in it. Pompian (2006) mentions the mistakes that usually occur as a result of overconfidence behavior in relation to investments in the financial markets, (1) Overconfidence can lead investors to make excessive trading as an effect of the belief that they have special knowledge that they do not actually have, (2) Overconfidence causes investors to overestimate the ability to evaluate an investment, (3) Overconfidence can lead investors to underestimate on the risk and tend to ignore the risk. (4) Overconfidence causes a tendency of investors' investment portfolio to be under-diversified.

The theory of excessive trading argues that high overconfidence behavior will lead to the tendency of investors to practice aggressive and excessive trading strategies. Ultimately, it will lead to poor investment performance. The research presented by Benos (1998) using the auction market research, concludes that overestimating the accuracy of the information will lead to increase trading volume of investors. Gervais and Odean (2001) find that the increase in trading volume and volatility will lead to less and even negative investors' earning. Daniel et al. (1998) also conclude that the average behavior of overconfidence in financial markets may cause harmful effects, but in some cases it may generate returns in excess of rational investors. Others empirical test of excessive trading theory conducted by Graham et.al (2006), Grinblatt and Keloharju, (2009), Statman et.al (2003) and 
Glaser and Weber (2003). The results of these study find that the level of investor overconfidence affects trading frequency and trading volume. According to Benos (1998), investors who have high overconfidence level tends to overestimate the accuracy of their information and feel that they have a better capacity than others in evaluating the information, so it will cause investors to trade more frequently than other investors. Graham et al. (2005), Grinblatt and Keloharju (2009), find that the level of trading frequency of an investor is affected by the level of investor overconfidence. Statman et.al (2003); Glaser and Weber (2003) show that investors with high level of overconfidence have a tendency to trade in large volumes. This greater the desire to do trading will make their transactions over-aggressive, which are indicated by a higher trading frequency and more transaction volume.

H1: High overconfidence investors have higher frequency and larger trading volume than low overconfidence investors

Pompian (2006) explains that high level overconfidence causes investors to underestimate the risk or tend to ignore the risk. One of investment risk in stock is the risk associated with stock price declines (capital loss). Information related to the global market, macroeconomic, and issuers' fundamentals can be used to explain the increase or decrease in stock prices. The existence of bad news can cause the stock price decline because investors' response to the negative news will result in more sales than purchases. But the investors who have high overconfidence tends to ignore the risk from the information because they have their own beliefs about choice, so that such information should not affect trading activity of investors. Testing how strong the effect of overconfidence level factors on investors' trading activity is necessary for testing for the presence of information or signaling test. If the level of overconfidence have powerful influence to trading activity, there is no signaling motive effects (Kufepaksi, 2007). The presence of bad news is used to test how strong the influence of overconfidence on the trading activities. Investors who have high overconfidence are not too concerned to the bad news information because they have their own beliefs about choice. Consequently, that information will not affect their trading activity.

H2: In the group of investors with high level of overconfidence, there is no difference in trading activity before and after the bad news.

H3: In the group of investors with low level of overconfidence, the trading activity is lower after the bad news.

Gervais and Odean (2001) argue that the increase in trading volume and volatility will cause investors gains to become lower or even negative. Kirchler and Maciejovsky (2002) argue that the overconfidence investors who trade too much will experience reduced outcome (earnings) and often invest in stocks that have negative earnings. Biais et.al (2002) find that behavioral tendency of overconfidence causes investors to invest in stocks that do not provide benefits.

H4: Investors with high level of overconfidence have lower profits compared to investors with low level of overconfidence.

\section{Research Method}

Participants of this research are undergraduate students who have covered minimal courses on financial management and have never invested in the capital market. The use of students as a subject because they represent the original characteristics that can be manipulated easily in the threatments of experiment. In addition, students have adequate academic provision that would facilitate their understanding of investment (Kufepaksi, 2007). We use students of Department of Management, Sebelas Maret University, Indonesia. This research is an experimental research. We employ a mixed design of between-subject and within-subject design. The between-subject design is utilized to compare the trading frequency, trading volume, and return between the group of investors with high and low overconfidence level. Within subject design is utilized to compare the trading frequency and trading volume before and after bad news in the high and low overconfidence levels. The designs of the experiment in this study are summarized in Table 1, measurement of variables in Table 2 and method of hypothesis testing in Table 3:

\section{Result of Hypotheses Testing}

Based on Table 4, in the group of high overconfidence, the average frequency of total trading amounted to 10.95 times with the lowest trading frequency of 3 times and the highest is 22 times. Average total trading volume totaled 167,23 lots with the lowest volume of 60 lots and the highest volume of 485 lots. Return is an average of $-5.546 \%$ with the lowest profit is $-21.65 \%$ and the highest profit of $5.64 \%$. Whereas in the group of low overconfidence, the average total trading frequency is 7.63 times as much trading with the lowest frequency of 2 times and 16 times the highest. Average total trading volume totaled 118.42 lot with the lowest volume of 35 lots and the highest volume of 270 lots. Gain (return) earned an average of $-0.531 \%$ with the lowest profit is $-10.13 \%$ and the highest profit of $6.64 \%$.

The results of testing H1 (table 5) indicate that there are differences in trade activity between high overconfidence group and low overconfidence group using trading frequency and trading volume as proxy. These results are consistent with previous findings that high level of overconfidence will lead to high trading 
frequency (Graham et.al, 2006; Grinblatt and Keloharju, 2009) and cause the volume of transactions becomes larger (Statman et al, 2003; Glaser and Weber, 2003). These results show that in the context of theoretical research in Indonesia, the excessive trading theory is supported.

The results of testing $\mathrm{H} 2$ and $\mathrm{H} 3$ are given in Table 6 and Table 7. In the group of high overconfidence, the existence of bad news does not affect trading activities. On the contrary, among the investors with low level of overconfidence, the bad news will cause a decline in trading activites. The results of this study indicate that the in group of investors with high overconfidence, there is no signaling motive effects, a tendency to not response the public information to make decision. While in the group of investors with low levels of overconfidence, with characteristics that do not have high confidence in the ability, knowledge and private information they possess, they will tend to use public information to be processed as an input in decision-making (Klayman, 1999).

The result of testing H4 is shown in Table 8. The investment return of the groups with high overconfidence is significantly lower than the low overconfidence. This research provides empirical evidence that high overconfidence behavior eventually led to lower investment performance. Gervais and Odean (2001) argue that the increase in trading volume and volatility will lead to investors gains become less and even negative. The results of this study are consistent with the findings Biais et al. (2002), Kirchler and Maciejovsky (2002).

\section{Summary and Concluding Remarks}

Our experimental study provides empirical evidences supporting the theory of excessive trading which argue that high overconfidence behavior will lead to the tendency of investors to take aggressive and excessive trading strategy. Ultimately, it will lead to poor investment performance. Using the role of "bad news", we test the strength of overconfidence in influencing investment decision and we find that the existence of bad news does not reduce the effect of overconfidence on trading activity. The overall results are in line with the major previous studies working on this issue. We recommend practical suggestions as implication of the results that investment companies need to provide insight and training to the investors, brokers and investment managers about investment mistakes that can occur because of overconfidence behavior. Overconfidence leads to too frequent transactions and too excessive volume of transactions which in turn result in a lower investment performance. Hopefully, training to improve knowledge and understanding of this overconfidence behavior will reduce errors that result in a decrease of invested wealth of investors.

Nevertheless, we point out several limitation of this research. First, the proxy variables used to measure trading activity are limited to the frequency and volume of trading. Other variables, such as the bid ask spread, are not entered into analysis. In this experiment, the average frequency of trading is relatively low, because many buy orders or sell orders are not executed. Participants rarely place a buy order at the best offer or sell order at the best bid. They would rather place a limit order (make an order in the queue). Second, the overall duration of this experimental study is relatively long (4 hours or 240 minutes, divided into two sessions). Long-duration experiments may cause the maturation effect, changes in participants' behavior that may be caused by the influence of other factors that occurred during the experiment but not due to deliberate in the experimental treatment.

\section{References}

Barber, B.M., \& Odean, T. (2000). Trading is Hazardous to Your Wealth: the Common Stock Performance of Individual Investors. Journal of Finance, 55(2), 773-806. doi:10.1111/0022-1082.00226, http://dx.doi.org/10.1111/0022-1082.00226

Barber, B.M., \& Odean, T. (2001). Boys Will Be Boys: Gender, Overconfidence, and Common stock Investment. Quarterly Journal of Economics, 116(1), 261-292. doi:10.1162/003355301556400, http://dx.doi.org/10.1162/003355301556400

Benos, Alexandros V. (1998). Aggressiveness and Survival of Overconfident Traders. Journal of Financial Markets 1, 353-383. doi:10.1016/S1386-4181(97)00010-4, http://dx.doi.org/10.1016/S1386-4181(97)00010-4

Biais, B., Hilton, D., Mazurier, K., \& Pouget, S. (2002). Psychological Traits and Trading Strategies. C.E.P.R. Discussion Papers 3195.

Bloomfield, R., Robert, L., \& Nelson, M. (1999). Confidence and Welfare of Less Informed Investors. Accounting, Organizations and Society, 24, 623-47. doi:10.1016/S0361-3682(99)00025-2, http://dx.doi.org/10.1016/S0361-3682(99)00025-2

Charness, G., \& Gneezy, U. (2003). Portfolio Choice and Risk Attitudes: An Experiment. Working Paper. [Online] Available: http://papers.ssrn.com/sol3/papers.cfm?abstract_id=397300

Cheng, P.Y.K. (2007). The Trader Interaction Effect on the Impact of Overconfidence on Trading Performance: An Empirical Study. Journal of Behavioral Finance, 8(2), 59-69.

Daniel K., Hirshleifer D., \& Subrahmanyam A. (1998). Investor Psychology and Security Market Under and Overreaction. Journal of Finance, 53 (6), 1839-1885. doi:10.1111/0022-1082.00077, http://dx.doi.org/10.1111/0022-1082.00077 
Gervais, S., \& Odean, T. (2001). Learning to be Overconfident. Review of Financial Studies, 14(1), 1-27. doi:10.1093/rfs/14.1.1, http://dx.doi.org/10.1093/rfs/14.1.1

Glaser, M., \& Weber, M. (2003). Overconfidence and Trading volume. Working Paper. [Online] Available: http://papers.ssrn.com/sol3/papers.cfm?abstract_id $=471925 \&$ rec $=1 \&$ srcabs $=957504$

Graham, J., Harvey, C., \& Huang, H. (2006). Investor Competence, Trading Frequency, and Home Bias. Working Paper. [Online] Available: http://papers.ssrn.com/sol3/papers.cfm?abstract_id=620801

Grinblatt, M., \& Keloharju, M. (2009). Sensation Seeking, Overconfidence, and Trading Activity. Journal of Finance 64(2), 549-578. doi:10.1111/j.1540-6261.2009.01443.x, http://dx.doi.org/10.1111/j.1540-6261.2009.01443.x

Kirchler, E., \& Maciejovsky, B. (2002). Simultaneous Over- and Underconfidence: Evidence from Experimental Asset Markets. Journal of Risk and Uncertainty, 25(1), 65-85. doi:10.1023/A:1016319430881, http://dx.doi.org/10.1023/A:1016319430881

Klayman, J., Soll, J. B., González-Vallejo, C., \& Barlas, S. (1999). Overconfidence: It Depends on How, What, and Whom You Ask. Organizational Behavior and Human Decision Process, 79(3), 216-47. doi:10.1006/obhd.1999.2847, http://dx.doi.org/10.1006/obhd.1999.2847

Kufepaksi, M. (2007). The Contribution of Self-Deceptive Behavior on Price Discovery: An Experimental Approach. Proceedings of the 13th Asia Pacific Management Conference, Melbourne, Australia, 56-66.

Lichtenstein, S., \& Fischhoff, B. (1977). Do Those Who Know More Also Know More About How Much They Know. Organizational Behavior and Human Performance, 20(2), 159-83. doi:10.1016/0030-5073(77)90001-0, http://dx.doi.org/10.1016/0030-5073(77)90001-0

Odean, T. (1998). Volume, Volatility, Price and Profits When All Traders Are Above Average. Journal of Finance, 53(6), 1887-1934. doi:10.1111/0022-1082.00078, http://dx.doi.org/10.1111/0022-1082.00078

Odean, T. (1999). Do Investors Trade Too Much. The American Economics Review, 89(5), 1279-98. doi:10.1257/aer.89.5.1279, http://dx.doi.org/10.1257/aer.89.5.1279

Pompian, M. M. (2006). Behavioral Finance and Wealth Management. John Wiley \& Sons Inc. New Jersey.

Sembel, R. (1996). IPO Anomalies, Truncated Excess Supply, and Heterogeneous Information. Ph.D Dissertation, University of Pittsburgh, Pittsburgh.

Statman, M., Thorley, S., \& Vorkink, K. (2003). Investor Overconfidence and Trading Volume. Working Paper. [Online] Available: http://papers.ssrn.com/sol3/papers.cfm?abstract_id=168472

Table 1. Design of Experiment

\begin{tabular}{|c|l|}
\hline Step & \multicolumn{1}{c|}{ Description } \\
\hline 1 & Calibration test to determine the level of subjects confidence \\
\hline 2 & $\begin{array}{l}\text { Based on calibration tests, determine the number of participants 60 people (30 men and 30 women) } \\
\text { who have a positive overconfidence score. }\end{array}$ \\
\hline 3 & $\begin{array}{l}\text { Participants are grouped into three groups: high, moderate, and low overconfidence level. Each group } \\
\text { consist of 10 men and 10 women. }\end{array}$ \\
\hline 5 & Prior to the simulation, participants are given explanations and guidance on the simulation mechanism. \\
\hline 5 & $\begin{array}{l}\text { Trading simulation experiment using software. Each participant in this study were given a virtual } \\
\text { start-up capital to invest Rp. 100.000.000, -. Experiments conducted over 4 (four) hours, divided into 2 } \\
\text { sessions. }\end{array}$ \\
\hline 6 & $\begin{array}{l}\text { At the end of the experiment, participants who received the highest gain of 1-5 will receive a cash } \\
\text { reward. While the other participants also earn cash for their participation in the simulation followed a } \\
\text { smaller number than the winner of the simulation }\end{array}$ \\
\hline
\end{tabular}

Table 2. Measurement of Variables

\begin{tabular}{|l|l|}
\hline \multicolumn{1}{|c|}{ Variables } & \multicolumn{1}{c|}{ Measurement } \\
\hline Overconfidence & $\begin{array}{l}\text { measured by using a test based on the calibration model Klayman et.al (1999) and } \\
\text { Kufepaksi (2007). }\end{array}$ \\
\hline Bad news & $\begin{array}{l}\text { announcement of loss and the recommendation to not buy (Stikel et.al, 1995; } \\
\text { Kufepaksi, 2007) }\end{array}$ \\
\hline Trading frequency & measured by the number of transactions conducted by the participants \\
\hline Trading volume & measured by the number of trading volume (lot) made by the participants \\
\hline Return & $\begin{array}{l}\text { measured by profit or loss obtained by investors in stock trading simulation divided by } \\
\text { the initial capital multiplied by 100\% }\end{array}$ \\
\hline
\end{tabular}


Table 3. Method of Hypothesis Testing

\begin{tabular}{|c|l|}
\hline Step & \multicolumn{1}{c|}{ Description } \\
\hline 1 & $\begin{array}{l}\text { One-way analysis of variance (ANOVA) used to test whether there are significant differences in value } / \\
\text { overconfidence scores between the groups. } \\
\text { Bonferroni test used to test whether there are significant differences between the combination of each } \\
\text { group (post hoc). }\end{array}$ \\
\hline 2 & $\begin{array}{l}\text { Independent samples t-test is used to test H1 (between subject), whether there are differences in trade } \\
\text { activity between the high overconfidence and low overconfidence groups. }\end{array}$ \\
\hline 3 & $\begin{array}{l}\text { Paired samples t-test is used to test H2 and H3 (within subject), whether there are differences in trading } \\
\text { activity before and after the bad news, both on the high and low overconfidence level groups. }\end{array}$ \\
\hline 4 & $\begin{array}{l}\text { Independent samples t-test is used to test the H4 (between subject), whether there are differences in } \\
\text { return between high overconfidence and low overconfidence level groups. }\end{array}$ \\
\hline
\end{tabular}

Table 4. Descriptive Statistics

\begin{tabular}{|l|l|l|l|l|l|l|l|l|}
\hline \multirow{2}{*}{ Variables } & \multicolumn{4}{|c|}{ High Overconfidence } & \multicolumn{4}{c|}{ Low Overconfidence } \\
\cline { 2 - 9 } & \multicolumn{1}{|c|}{ Min } & \multicolumn{1}{|c|}{ Max } & \multicolumn{1}{|c|}{ Mean } & Std. Dev. & \multicolumn{1}{c|}{ Min } & \multicolumn{1}{c|}{ Max } & Mean & Std. Dev. \\
\hline TFT & 3 & 22 & 10.95 & 4.362 & 2 & 16 & 7.63 & 3.318 \\
\hline TFT_pre & 1 & 14 & 5.62 & 2.628 & 1 & 10 & 4.90 & 2.193 \\
\hline TFT_post & 1 & 13 & 5.32 & 2.712 & 0 & 6 & 2.72 & 1.485 \\
\hline TVT & 60 & 485 & 167.23 & 90.816 & 35 & 270 & 118.42 & 58.461 \\
\hline TVT_pre & 20 & 305 & 82 & 50.458 & 25 & 174 & 71.30 & 34.883 \\
\hline TVT_post & 30 & 240 & 85.23 & 56.198 & 5 & 100 & 47.13 & 27.921 \\
\hline Return & -21.65 & 5.64 & -4.546 & 6.71286 & $-10,13$ & 6,64 & -0.531 & 4.93093 \\
\hline
\end{tabular}

Note: TFT (Total frequency of trading), TFT_pre (Frequency of trading before bad news), TFT_post (Frequency of trading after bad news), TVT (Total volume of trading), TVT_pre (Total volume of trading before bad news), TVT_post (Volume of trading after bad news), Return (Return of trading in percent)

Table 5. Test of the difference of trading activities between high and low overconfidence

\begin{tabular}{|l|c|l|l|}
\hline \multirow{2}{*}{ Variables } & Mean differences & \multicolumn{2}{c|}{ Test of mean differences } \\
\cline { 3 - 4 } & & \multicolumn{1}{c|}{$\mathrm{t}$ value } & \multicolumn{1}{c|}{$\mathrm{p}$-value } \\
\hline Trading frequency & 3.325 & $3.837 * * *$ & 0.000 \\
\hline Trading volume & 48.800 & $2.858 * * *$ & 0.005 \\
\hline
\end{tabular}

Note : ***: Significant $\mathrm{p}=0.01, * *:$ Significant $\mathrm{p}=0.05, *$ : Significant $\mathrm{p}=0.1$

Table 6 . Test of trading activity difference before and after bad news in the group of high overconfidence

\begin{tabular}{|l|c|l|c|}
\hline \multicolumn{1}{|c|}{ Variables } & Mean differences before and & \multicolumn{2}{c|}{ Test of mean differences } \\
\cline { 3 - 4 } & after bad news & t value & p-value \\
\hline Trading frequency & 0.300 & 0.616 & 0.542 \\
\hline Trading volume & -3.225 & -0.363 & 0.719 \\
\hline
\end{tabular}

Note: $* * *$ : Significant $\mathrm{p}=0.01,{ }^{* *}:$ Significant $\mathrm{p}=0.05, *$ : Significant $\mathrm{p}=0.1$

Table 7. Test of trading activity difference before and after bad news in the group of low overconfidence

\begin{tabular}{|l|c|l|l|}
\hline \multicolumn{1}{|c|}{ Variables } & $\begin{array}{c}\text { Mean differences before and } \\
\text { after bad news }\end{array}$ & \multicolumn{2}{c|}{ Test of mean differences } \\
\cline { 3 - 4 } & 2.175 & $7.916^{* * *}$ & 0,000 \\
\hline Trading frequency & 24.175 & $6.375^{* * *}$ & 0,000 \\
\hline Trading volume & &
\end{tabular}

Note: $* * *$ : Significant $\mathrm{p}=0.01, * *$ : Significant $\mathrm{p}=0.05, *$ : Significant $\mathrm{p}=0.1$

Table 8 . Test of average return difference between the group of high overconfidence and low overconfidence

\begin{tabular}{|c|c|c|c|}
\hline \multirow{2}{*}{ Variable } & Mean differences & \multicolumn{2}{c|}{ Test of mean differences } \\
\cline { 3 - 4 } & & t value & $\mathrm{p}$-value \\
\hline Return & -4.015 & $-2.156^{* *}$ & 0.038 \\
\hline
\end{tabular}

Note: $* * *$ : Significant $\mathrm{p}=0.01, * *$ : Significant $\mathrm{p}=0.05, *$ : Significant $\mathrm{p}=0.1$ 